\title{
The Relationship between Second Language Acquisition Process and English Language Teaching in Indonesia
}

\author{
Pritz Hutabarat \\ Maranatha Christian University \\ pritz.maranatha@gmx.com
}

\begin{abstract}
English as a global language is learned worldwide and a plethora of methods and approaches have been developed and practiced in English classrooms by dedicated teachers and students. Understanding the underlying theories of second and foreign language acquisition and learning will help both teachers and students in learning and teaching a target language. There has not been many researches conducted in the area, especially within Indonesian context. This research therefore attempts to fill in gaps in a way that it provides sufficient discussion of the theories and practice in English Language Teaching (ELT) in Indonesia in its conjunction with the second and foreign language acquisition theories. Twenty eight students specializing in teacher training participated in the research and two distinguished data collection methods were utilized; survey and interview. The results show that the students are not consistent with their opinions concerning to the theories of second or foreign language acquisition and learning in relation to the mastery of English as a foreign language in Indonesia.

Keywords: language learning, language acquisition, ELT
\end{abstract}




\section{INTRODUCTION}

English as a foreign language plays an important role not only in the international forum, but also in the various interactions in Indonesia. The use of English in Indonesia is undeniable. It is applied almost in all areas of life such as economics, social, education, health, and law. Companies advertise their products by the mean of English as the language is perceived to be more prestigious than Indonesian language.

In the area of education, some students start learning English as early as they can, although the government of Indonesia does not require primary schools to offer English as a subject. The President of Indonesia, Joko Widodo once said that the teaching of English in primary schools was eliminated and replaced by more hours studying Indonesian language so that the students will have greater sense of nationalism (Reviyanto, 2013). This policy makes Indonesia as the only country in ASEAN which does not have English as a mandatory subject at primary schools (Kirkpatrick, 2015). On the contrary, although English is not a mandatory subject, some parents still think that it is important for their children to learn English, and therefore enrolling their children in an English course expecting that they will be able to communicate in English. This is probably because the parents think that having the competence in English will help their children to compete in the more globalized world. This is in line with a recent study conducted by Pearson stating that nearly eighty percent of international companies consider English proficiency when recruiting (Maceda, 2014).

In English Language Teaching (ELT), teachers need to understand how children acquire or learn a second or foreign language in order to help them planning and teaching English as a foreign language in Indonesia. Furthermore in the discussion, this study assumes that the approaches, methods, and procedures of teaching English are similar in the context where English is a second language or English as a foreign language. Having comprehensive lesson plans will lead to the success of delivering effective teachings and in the end will produce satisfactory results. Teachers need to be aware of different styles and tendencies the way their students learn and as much as possible prepare their lessons to cater all of the learners. Teaching methods are closely related to certain philosophy underlying it, so accordingly, having solid understanding of language acquisition and learning theories will contribute to effective lesson planning and teaching.

In the Indonesian context, the teaching of English as a foreign language has been done for many years but does not seem to yield satisfactory results. In spite of various methods and approaches applied, the student's level of English is still relatively low. This posits serious problems in the practice of the teaching of English as a foreign language in Indonesia as indicated by the low competence score in the teacher competence test, which was only 34/100 for secondary school teachers (Roszandi, 2012). 


\subsection{Research Questions}

Three research questions are formulated to guide this study:

1. What are student's reflections of the theories of second language acquisition in relation to the teaching of English as a foreign language in Indonesia?

2. How does these reflections influence the way they teach English?

3. Which theories are most suitable for Indonesian learners?

This study is expected to give insight to the ELT teachers in better understanding of second language acquisition theories and practices. This paper are also benefit school administrators and government in which that it provides a thorough discussion in the area of second language acquisition especially in ELT in Indonesia.

\section{LITERATURE REVIEW}

\subsection{Second versus Foreign Language Acquisition}

There is sometimes a need to differentiate between second and foreign language acquisition. In the case of second language acquisition, the language plays an institutional and social role in the community (Ellis, 1994). For example, English as a second language is learnt in the United States, England, and Singapore. On the other hand, foreign language learning mostly takes place in language classrooms and taught as a subject. Second language acquisition has long been an interesting phenomenon to be discussed among the scholars, in fact it is still a subject of disagreements between many prominent experts in the areas of linguistics as well as psychology. The Universal Grammar (UG) is one of the recognized concept in second language acquisition states that the competence of L2 speakers is constrained and regulated by the same universal principles that govern natural language in general (White, 2003). Hymes (2001) on the other hand focuses on how a second language is acquired to function in social interaction in terms of communicative competence (Bagarić \& Djigunović, 2007 Vol.8). Another widely accepted notion is given by Krashen and Terrell (1980), who divided the process of learning and acquiring a language. Acquisition refers to subconscious process especially when children learning their first language and learning as intentional efforts made by learners of language (Bot, Wander, \& Verspoor, 2005). The principles of language of acquisition including critical period, affective factors, and instrumental motivation in language study play important role in language acquisition (Brown in Nurhayati, 2008a).

\subsection{Universal Grammar}

Universal Grammar (UG) is one of the most recognized concept states that the competence of L2 speakers is constrained and regulated by the same universal principles that govern natural language in general (White, 2003). Following Chomsky $(1959,1965,1975,1980,1981 \mathrm{a}, \mathrm{b}, 1986 \mathrm{~b}, 1999)$, White states that in a discussion about second language acquisition we should adopt a particular point of view on linguistic universals and take for granted specific assumptions about the nature of linguistic competence. Universal grammar is built upon some particular 
logical problems such as why children display linguistic abilities which is far beyond the input they have been exposed to, the notion stating that the language capacity is species specific, the fact that people can acquire a language regardless of their intelligence, the development of pattern follows similar patterns, different language different cultures and how a language is acquired at ease and rapidly. All of these phenomenon point to the presence of an innate component to language acquisition (2003).

Pesetsky summarizes the theory of Universal Grammar as he concludes the three main evidences about the existence and nature of UG. The first evidence comes from the discussion in the article on typology as the results of cross linguistic investigations of linguistic universals. Cross linguistic investigations observe whether a property found in one language is also found in other unrelated languages, and, if so, why. The second evidence concerning UG comes from investigation of language acquisition and learn-ability, especially as these investigations touch on issues of poverty of the stimulus arguments. The discussion on acquisition and learn-ability contributes aim to explain whether a property found in the grammar of an individual speaker is acquired by imitation of input data or whether some other reason for the existence of this property. Finally, research on modularity and language explains the notion of specially linguistic nature of UG. Features of language whose typological and acquisitional footprint suggests an origin in UG may be confirmed as reflections of UG if they reflect aspects of cognition that are to some degree language-specific and "informationally encapsulated." If a fact about an individual speaker's grammar turns out to be a fact about grammars of all the world's languages, if it is demonstrably not a fact acquired in imitation of input data, and if it appears to be specific to language, then we are warranted to suspect that the fact arose from a specific feature of UG (2009).

\subsection{Krashen's Five Hypotheses}

Krashen's theory of second language acquisition (1985) consists of five main hypotheses:

1. the Acquisition-Learning hypothesis;

2. the Monitor hypothesis;

3. the Natural Order hypothesis;

4. the Input hypothesis;

5. the Affective Filter hypothesis.

Krashen classifies the nature of language mastery into two main activities; acquiring and learning. The main difference between the two processes lays in the intentional factor for learning a language. Acquiring refers to unintentional activities of learning a language as observe in the first language acquisition. Learning on the other hand refers to intentional effort of acquiring a language, could be a second or foreign language which commonly occurs in a language classroom.

The monitor hypothesis states that the second language learners (L2) make use of their linguistic knowledge in the second language as a monitor as they are making utterances in L2. There are three types of L2 learners, namely under users, optimum users, and over users. Those who are under users tend to neglect the 
importance of having proper grammar when speaking or writing. They may seem to be fluent in L2 but when examine closely, ones will know that their utterances are grammatically incorrect. In the classroom, they are confident when talking to their peers and enjoy conversational activities. Over users are the opposite of under users to the point that they are so shy to make utterances. This shyness may impair their progress in the language learning. They spend too much time worrying whether they are making grammatical sentences or not. Some of the over users may end up becoming passive users of the language. Ideally we want our students to become optimum users which means that they are aware and make use of their linguistic knowledge when engage in communication but do not let this awareness interferes with the pace of the communication. We may occasionally hear them making grammar errors and mistakes, but in most cases we understand what they are talking about.

The natural order hypothesis argues that children develop their linguistic skills in the similar order such as the acquisition of present continuous form of verbs proceeds the mastery of singular form of verbs for third person singular subjects. Although this theory has been challenged by Gregg (1987) as cited by Romeo, its implication in the teaching of English has been significant through the natural approach (Romeo, 2000) as seen in the following:

The input hypothesis emphasizes the important of giving meaningful and relevant inputs to L2 learners to allow them absorbing the correct grammar, pronunciation, and intonation. If learners learn a language through meaningful interactions, they will acquire the target language naturally and they will have longer term memory of the things they have learnt. In the classroom, the teachers need to teach certain linguistic features within relevant contexts. This hypothesis does not support grammar translation method as it tends to teach a language through grammar drillings without paying attention to the context surrounding the utterances learnt.

The affective filter hypothesis acknowledges the significant role of motivation and other psychological aspects of a learning process. Affective filter includes all types of emotional factors in learning such as afraid in making mistakes, embarrassed to speak, feeling not ready to speak, etc. These feelings can affect the way learners participate in the learning process. Low affective filter students will easily discourage by mistakes, so they tend to avoid activities such as speaking and role playing. As a result they may make very slow progress in their learning as they are too scared to practice using the language. Teachers need to be aware of their student's affective filter level so that they may encourage them and assure them that the classroom is a supportive system for them to learn.

\subsection{The teaching of English as a second or foreign language}

English with its status as a global language has been an increasingly important subject to be taught in schools around the world including in Indonesian schools. In the big cities of Indonesia such as Jakarta, Surabaya, Medan and Bandung English is introduced from an early age whereas in the more remote areas it is taught from secondary level schools. According to Depdiknas, English as a subject is taught to support the development of the intellectual, emotional and social 
skills of the students, to assist the mastery of other subjects and to develop communication skills in English (Suherdi, 2012). This statement implies the importance of English acquisition for Indonesian students to develop their academic and non academic skills. This is in line with the general assumption about English as stated by Crystal (2003) where a language is acknowledged as a globally-used language, in this case English, it plays a special role that is recognized in every country. The acceptance of a language to become an international or a global language has a very strong connection with political, technological enhancement and economical power (Crystal, 2003).

In terms of the teaching of English as a second or foreign language, Anthony (1963), as quoted by Brown, listed three hierarchical elements in the teaching, namely approach, method, and technique. An approach is a set of assumptions dealing with the nature of language, learning, and teaching. Method is the overall plan for systematic presentation of language based upon a selected approach. Techniques are the specific activities applied in the classroom that are in line with a method and therefore are inspired by a specific approach (Brown, 2001). Brown revised the definitions and added two other terms, methodology and curriculum or syllabus. According to Brown, methodology relates to pedagogical practice in general (including theoretical underpinnings and related research). It deals with "how to teach" questions. Approach is theoretically well-informed positions and belief about language, the nature of language learning, and the applicability of both to pedagogical settings. Method is a generalized set of classroom specifications for accomplishing linguistic objectives. Curriculum/ syllabus are designed set to carry out a particular language learning program. Techniques are any activities done in the classroom to achieve the learning objectives.

Krashen offers another perspective with regard to language teaching by stating that language acquisition does not require extensive use of conscious grammatical rules, and does not require tedious drill. It does not occur overnight, however. Real language acquisition develops slowly, and speaking skills emerge significantly later than listening skills, even when conditions are perfect. $\mathrm{He}$ concludes that the best methods are therefore those that supply comprehensible input in low anxiety situations, containing messages that students really want to hear. These methods do not force early production in the second language, but allow students to produce when they are ready, recognizing that improvement comes from supplying communicative and comprehensible input, and not from forcing and correcting production. (1981)

Krashen further explains about the importance of language input to the process of language acquisition. He said that the input should be comprehensible by the students at their language level. It means that in the second language class, a teacher must be aware of the level of fluency of his students and adjust the language input accordingly although in natural immersion we cannot limit the language input (1981).

One of the teaching practices aiming to cater contextual and meaningful language input to the students is done in bilingual and immersion education where the language is not only be taught as a language subject but also is infused in the 
teaching of other subjects as the medium of instructions. This concept is known as immersion programs. The idea behind full immersion programs is that the students and the teachers are constantly exposed to more authentic materials of English and it provides opportunities for them to learn the language in natural settings as they are constantly interacting with the target language in meaningful ways.

Hadley mentions that the new foreign language standards emphasize the need to integrate the teaching of culture in the language curriculum, a need that has been accentuated in the professional literature for many years. He says that this focus on the importance of cultural learning is rooted in at least two widely held beliefs among foreign language professionals: (1) that language study is an essential component in the curriculum, in part because it can lead to greater cross-cultural understanding, and (2) that language and culture are inseparably intertwined (Hadley, 2001). A recent study shows that immersion programs are the fastest growing and most effective type of foreign language program currently available in U.S. schools. Most immersion students can be expected to reach higher levels of second language proficiency than students in other school-based language programs (Met, 1998). Becoming bilingual opens the door to communication with more people in more places, and many parents want to provide their children with skills to interact competently in an increasingly interdependent world community (Fortune \& Tedick, 2003). Modeled after the pioneering French immersion programs developed in Canada in the 1960s, foreign language immersion programs in the United States are designed to enrich the education of native-English-speaking students by teaching them all of their academic subjects in a second language. The goal is for students to become proficient in the second language and develop increased cultural awareness while reaching a high level of academic achievement as the students learn all of the subjects in the target language not in their mother tongue (Fortune \& Tedick, 2003).

\section{RESEARCH METHOD}

This chapter presents the research methodology used in this research and provides information about the population and the sample. Besides, it describes the data collection instruments and procedures. Finally, it describes the validity and reliability of the instruments and gives information about the data analysis.

The population of this research is 28 third semester students of English Department who were doing their final exam in Second Language Acquisition (SLA) in the last semester. The major source of data used to find answers to the research questions are document analysis of the written work of the participants, and interviews. The data were collected from the participants' mid-term examination, in which they were required to answer three questions concerning ELT theories. This research only focuses on the students' reflection on SLT theories. Since there are only 28 data to analyze in this research, the researchers have decided to use all the data. Interviews were done to clarify some findings found in the mid-term paper, and to further elaborate the participants' reflections of their teaching practice.

This research is a qualitative study thus follows qualitative data analysis procedures which start with gathering raw information from the test and interviews. Next, the answers are collected and tabulated to see the dominant themes arising 
from the data. A table is drawn to put together the theories according to the emerging themes. SLA theories are used as an instrument to analyze the students' reflection on how they have learned English and how they see the connections between the theories of SLA and English Language teaching (ELT). Finally, the researcher concludes the most adopted theories chosen by the students and give suggestions for further researchers.

\section{FINDINGS AND ANALYSIS}

In this chapter, the results of the analysis are presented. The analysis is based on the students' responses to question 1 and question 2 (see Appendix) when doing their mid-term exam concerning Second Language learning. The results are presented in tables as seen in the following:

Tabel 1 Communicative Competence vs. Academic Competence

\begin{tabular}{|c|c|c|c|}
\hline No. & $\begin{array}{l}\text { Communicative } \\
\text { Competence }\end{array}$ & $\begin{array}{l}\text { Academic } \\
\text { Competence }\end{array}$ & Note \\
\hline 1 & $\mathbf{x}$ & & \\
\hline 2 & & $\mathrm{x}$ & \\
\hline 3 & $\mathbf{x}$ & & \\
\hline 4 & $\mathbf{x}$ & & \\
\hline 5 & & $\mathrm{X}$ & \\
\hline 6 & & $\mathrm{x}$ & \\
\hline 7 & $\mathbf{x}$ & & \\
\hline 8 & & $\mathrm{x}$ & \\
\hline 9 & $\mathbf{X}$ & & \\
\hline 10 & $\mathbf{x}$ & & \\
\hline 11 & $\mathbf{x}$ & & \\
\hline 12 & & $\mathrm{x}$ & \\
\hline 13 & $\mathbf{x}$ & & \\
\hline 14 & $\mathbf{x}$ & & \\
\hline 15 & $\mathbf{x}$ & & \\
\hline 16 & $\mathbf{x}$ & & \\
\hline 17 & $\mathbf{x}$ & & \\
\hline 18 & & $\mathrm{x}$ & \\
\hline 19 & $\mathbf{x}$ & & \\
\hline 20 & & $\mathrm{x}$ & \\
\hline 21 & & $\mathrm{x}$ & \\
\hline 22 & $\mathbf{x}$ & & \\
\hline 23 & $\mathbf{x}$ & & \\
\hline 24 & $\mathbf{x}$ & & \\
\hline 25 & $\mathbf{x}$ & $\mathrm{x}$ & \\
\hline 26 & & $\mathrm{x}$ & \\
\hline Total & 18 & 10 & \\
\hline
\end{tabular}


From Table 1, it can be seen that 17 students have chosen Communicative Competence as their preference, 9 students prefer Academic Competence, while only 1 student has chosen both of the approaches. Referring to Communicative Competence, the students find that it is easier to use a second language as if it were their native language. In other words, they do not pay much attention to grammatical rules or usage. Therefore, for them, fluency is more important than accuracy. Besides, they hope that in the long run they will become more proficient in the second language as what they have done when acquiring their native language. Those students can be categorized as "underuser" according to Krashen's Monitor hypothesis (1985).

On the other hand, 9 students have chosen Language Learning as their priority. Those students believe that learning should come first before acquiring. As soon as they have mastered the grammatical rules and vocabulary, they feel confidence to use the second language. Those students belong to the "overusers" who rely on their conscious knowledge all the time. For them, accuracy is more important than fluency.

Surprisingly, only 1 student has chosen both Communicative Competence and Academic Competence. Referring to Krashen's Monitor hypothesis (1985), this particular student is classified as "optimal users". For her, there must be a balance between "usage" (what rules to use) and "use" (how rules to use). In this way, one can produce grammatical sentences though not fluent, for example, in speaking.

Tabel 2 Acquring vs Learning Language

\begin{tabular}{|c|c|c|c|}
\hline No. & $\begin{array}{l}\text { Acquiring } \\
\text { Language }\end{array}$ & $\begin{array}{l}\text { Learning } \\
\text { Language }\end{array}$ & Note \\
\hline 1 & $\mathbf{x}$ & & \\
\hline 2 & $\mathbf{x}$ & & \\
\hline 3 & $\mathbf{x}$ & & \\
\hline 4 & $\mathbf{x}$ & & \\
\hline 5 & & $\mathbf{x}$ & \\
\hline 6 & $\mathbf{x}$ & & \\
\hline 7 & $\mathbf{x}$ & & \\
\hline 8 & & $\mathbf{x}$ & \\
\hline 9 & $\mathbf{x}$ & & \\
\hline 10 & $\mathbf{x}$ & & \\
\hline 11 & & $\mathbf{x}$ & \\
\hline 12 & & $\mathbf{x}$ & \\
\hline 13 & & $\mathbf{x}$ & \\
\hline 14 & & $\mathbf{x}$ & \\
\hline 15 & & $\mathbf{x}$ & \\
\hline 16 & & $\mathbf{x}$ & \\
\hline 17 & & $\mathbf{x}$ & \\
\hline 18 & $\mathbf{x}$ & & \\
\hline 19 & & $\mathbf{x}$ & \\
\hline 20 & & $\mathbf{x}$ & \\
\hline
\end{tabular}




\begin{tabular}{|l|l|l|l|}
\hline 21 & $x$ & & \\
\hline 22 & & $x$ & \\
\hline 23 & & $x$ & \\
\hline 24 & & $x$ & \\
\hline 25 & & $x$ & \\
\hline 26 & x & & \\
\hline TOTAL & 10 & 16 & \\
\hline
\end{tabular}

From Table 2, it can be seen in the first column that 10 students consider acquiring language to be more significant than learning language. This indicates that acquiring language should be done earlier than learning language. In other words, a learner has to learn either a second language or a foreign language he/she learns a native language or the first language. From their responses, it can be inferred that they have applied theories of second language learning as adopted by the following linguists.

However, from the second column it can be concluded that 16 students prefer learning language to acquiring language. They find that it is more appropriate to learn a second language before they are able to use it. In other words, the study of grammar should be done first before using the language. This view is contrary to language acquiring. Comparing students' perspective in second language learning, it is obviously seen that students who choose learning language outnumber those who are in favor of language acquiring.

The areas of discussion are in line with the research questions guiding this study which include the acquiring process and the practice of teaching English. Students' perceptions of how they acquire English are compared with the theories of second language acquisition. The pedagogical implications of such perceptions are analyzed through the students plan and execute their lesson plans in the classroom. The findings obtained from the document analysis have been analyzed and will be presented in line with the research questions: What are student's reflections of the theories of second language acquisition in relation to the teaching of English as a foreign language in Indonesia? Due to the limitation of the research, only 13 data and their analysis are presented in this research as in the following:

From student 1 we can observe that the student thinks that speaking is the most important skill in acquiring English. He also mentions the importance of having high motivation in learning English that he uses English not only in the classroom during the English lessons, but also outside of the classroom in his interactions with other people. He strongly agrees with communicative competence approach to acquiring a foreign language. The student reflects his experience in learning English similar to Krashen's theory on the affective filter in learning. A student who has high affective filter will be very careful in engaging in a conversation or even in collaborative activities in the classroom as he would feel insecure about sharing his opinions worrying that other students would ridicule him. The student also sees the relationship between knowledge and performance in learning English in which he thinks that having a sufficient knowledge about the language (grammar rules) will help him in developing communicative competence. 
He also points out the importance of developing fluency in English as well as improving accuracy of the utterances. He believes that he must have an intrinsic motivation in which he set up his personal goal in learning English.

From student 2, it is clear that the dominant aspect in the student's success of struggle in learning English is related to her mental state (affective factor). The student was shy and afraid of making mistakes which has hindered better progress in her English learning. The way the teacher made her feel really affected her attitude towards English lessons. Given a different setting, where she hosted foreigners and therefore used English with them, she felt that she could develop her English better.

Student 3 mentions several important themes in learning English namely the importance of developing communicative competence, the development of English skills, the role of student's first language in learning a second or foreign language, and the three statues of a language usage. The student thinks that he needs to develop communicative skills in order to function effectively in English. He is aware of the two different types of competences; academic and interpersonal competence. Academic competence normally is developed in a formal setting such as at schools or English courses. Interpersonal skills are developed through meaningful interactions in the target language. The student also points out the importance of developing English skills to help him communicate better.

In terms of the role of student's first language in the learning process, the student states that L1 can be used in learning a second or foreign language. The student refers to the potential of L1 knowledge to be transferred into L2. By doing so, the students will understand some grammar rules of L2 faster as he has already had similar concepts in L1.

The last point mentioned is about the three different statues of language usage. The respondent is aware that in order to maintain his ability to communicate in English he must use English quite regularly, so that it does not become dormant. The more frequent a language is used, the more active it becomes and it will be easier for the user to access it. Students who learn English as a foreign language often lose their ability in communicating using the language due to the rarity of using English in their daily interactions.

Student 4 emphasizes the importance of motivation in learning English as a second or foreign language and the benefits of learning English. The respondent emphasizes the significance of having high motivation in the success of learning English. He is aware that there are extrinsic motivation and intrinsic motivation. Extrinsic motivation comes from outside of the learners, can be from their teachers, parents, or friends. The kinds of extrinsic motivation vary from verbal to material encouragement. Intrinsic motivation relates to the inner drive of a learner to master a target language. Someone with high intrinsic motivation does not really need outside encouragement as he himself has such a desire to be successful in learning English. The respondent also mentions some benefits of learning English such as the opportunity to meet and relate to foreigners, better cross-cultural understanding and becoming more open-minded. With the ability to communicate in English, students will be able to make contact with people from other countries. This communication requires developed English skills and confidence. The more we know a culture the 
better we appreciate the culture and learn about it. It is also supported by Karsono's research (2014) implies that giving comment and feedback after seeing their friends' performances made them enthuastic and encourage to English speaking, they had real-life communication,authentic activities, shared knowledge and meaningful learning.

Student 5 emphasizes the importance motivation in learning English. The student claims that she really enjoyed learning a second or foreign language especially when she experienced small successes along the way. However, she also experiences being de-motivated when she felt that she did not making satisfactorily progress in her study which led her to think that learning a second language was difficult. She saw the ability of speaking a second language has a positive effect on her self esteem as she thought that it was cool to be able to speak in a foreign language. She believes that in order to be successful in learning a second or foreign language, the anxiety level should be low. If the anxiety level is low, she is not afraid of making mistakes when communicating in English. Therefore, she keeps on using English in her interactions with other English language learners or native speakers outside of the English classroom. On the other hand, she also acknowledges the importance of having a sufficient understanding of grammar rules in developing communicative competence in general. She mainly gains her grammatical knowledge through formal learning activities in the classroom.

Student 6 acknowledges the benefits from having an early start in learning English as a second or foreign language as her parents introduced her with some English vocabulary. From this introduction she has developed a very positive attitude towards the language as well as the culture in a wider scope. The fact that she also enjoys learning English through listening to English songs indicates that there are stages in her life where she acquired English through meaningful interactions in English. Furthermore, she also develops her English competence through attending formal English classes where she learns English grammar rules, pronunciation, and some conventions in English. In the class, she experienced being taught in naturalistic manner where the teachers would mostly use English as the medium of instruction. This exposure has further developed her English level of proficiency. In the end she mentioned about the importance of having motivation, which she receives it from her parents, in learning English.

Student 7 really appreciates acquiring process when it comes to be able to communicate in a second or foreign language. She develops her English competency through meaningful interactions with other English speakers whether through online or offline conversations. At the moment she is learning English formally as she attends the Faculty of Letters of a university in Bandung. She often feels frustrated when she does not have opportunities to apply the knowledge which she learns from the lessons. This is probably as a result of her experience in acquiring English where she feels the need to practice her knowledge in everyday conversations. Furthermore, it is clear that the student has a good motivation in learning English as she willingly uses English outside of the classroom regardless of the struggles she has to face in maintaining the conversations. She mentions some bad experience in using English when the person she was talking to suddenly abandoned the 
conversation. This she believes is due to misunderstanding between the speakers. Instead of being discouraged, she uses this experience to boost her motivation to improve her communicative competence.

Student 8 thinks that having grammatical knowledge and content knowledge is very important to build communicative competence. Moreover, he thinks that to learn a language means that we should learn it step by step following zone proximal development theory which says that the best way of learning a second or foreign language is if we learn it just one level above our current level of ability (i+1). He also regards having the content knowledge, mostly related to having a wide range of vocabulary, is necessary in order to maintain a conversation.

During his learning process, he came across some difficult situations where he found it hard to understand his counter communicator in a conversation. Some of the difficulties are related to incorrect pronunciation and lack knowledge of the subject matter. He realizes that he will face difficulties when talking to people in English no matter how knowledgeable he is about the grammar rules. In the end, he mentions about the anxiety factor in learning English. He says that often he is afraid of making mistakes when using English. He is also aware that there are three types of grammar users; under-users, over-users, and optimal-users, and he sees himself as an optimal-user or the grammar rules.

Student 9 acknowledges that there are several factors contributing to the success of learning/acquiring English as a second or foreign language. The factors are the important of acquiring the language through daily conversations, the role formal learning, the role of L1 in learning and L2, and the importance of affective factor in learning English. The respondent strongly believes that the best of to learn a second language is by acquiring it through meaningful interactions where we actually use the language in a conversation. She compared it with learning vocabulary in her reading class where she could only remember the words for some weeks to then forget all about it completely. Her experience shows that by using the vocabulary in a natural conversation is far more effective. She confesses that she can remember the words that she used in the conversations with her foreign friends. Moreover, she also mentions about the role of L1 in learning an L2 where she thinks that if the grammar or pronunciation of L1 are quite similar with those in L1 then she can use the L1 knowledge to learn an L2. She also states that she uses her knowledge of grammar rules to edit her utterances. Finally, she acknowledges the importance of affective factors in the success of L2 learning.

Student 10 thinks that having early exposure of the target language is very beneficial in terms of gaining higher proficiency level. He also mentions about the stages of L2 acquisition where children normally start understanding only concrete concepts. So using their surrounding objects to learn a second language can be very beneficial. All in all the respondent seems to favor acquisition process through meaningful interactions in learning English rather than learning English in a formal classroom setting as it promotes a more naturalistic development stages of acquiring a language. In the end he also poses a suggestion to English teachers to use reward in motivating their students in the class. 
Student 11 elaborates some factors which affect the process of learning/acquiring a second language. The first factor is the importance of having sufficient knowledge of the subject being discussed. The respondent argues that without sufficient knowledge someone will fail to give appropriate response should it been required. Secondly, she mentions the importance of knowing grammar rules in order to produce accurate utterances, although, she also warns the language learners not to worry too much about making mistakes as the most important thing is how to understand each other. The third factor relates to the roles of natural conversations. She believes that a language is best learnt through meaningful and natural conversation, away from classroom interactions. Lastly, she mentions about the range of politeness when we use a language. As a language learner we should be aware that there are levels of politeness when talking to other people and if we fail to comply to the conventions then the goal of the conversation may not be achieved.

Student 12 really values the interactions with native speakers of the target language as a primary way to learn a second or foreign language. Furthermore, she mentions the roles of grammar rules in monitoring the utterances and the importance of using simple vocabulary in expressing her ideas or opinions.

\section{CONCLUSION AND SUGGESTION}

\subsection{Conclusion}

After analyzing the data, the research comes to the following conclusion: First, some respondents prefer applying the first approach, namely applying learning English as a foreign language; whereas others prefer applying the method of acquiring a second language as they do with their mother tongue. From their responses the research finds out that the answers to the teaching of a second language are different.

From the first question that they answer, it can be concluded that most of the respondents have chosen academic competence rather than interpersonal competence in teaching a second or foreign language. The first group of respondents argues that before they can communicate in the target language (TL), they have to master the basic grammar and a sufficient number of vocabularies. Without grammar and vocabulary, it is hardly possible to produce correct expressions or sentences in the TL. On the other hand, the other group prefers acquiring a second language they way they learn their mother tongue. They argue that fluency is more important than accuracy. Besides, they mention that accuracy can be gained through continuous practice and improvement.

Referring to the second question, concerning Krashen's Monitor Hypothesis, some respondents belong to under users, some optimum users, and others overusers. As far as underusers are concerned, they tend to neglect grammar when speaking or writing. Optimum users can see that there must be a balance between linguistic knowledge and communication skill. While speaking or writing, they are aware of using appropriate grammar; however, it does not bother them or even spoil their production either in the form of speaking or writing. The last group is over users who are too cautious about linguistic competence that they do not have 
confidence in speaking and writing. Consequently, they become slow learners or even incompetent in communication using a second language.

In answering the third question, concerning the respondents' preference of using any particular method, respondents have a different approach for their preference, which is based on their experience, either in class or outside class. It seems that at this stage respondents are not yet ready to give their stance regarding language learning and acquiring language.

\subsection{Suggestion}

First of all, this research suggests that there should be a further research, preferably a quantitative one. There should be two groups of learners as respondents. The first group is taught by using learning a foreign language approach, while the other uses acquiring a second language approach. After analyzing the result, the researcher can conclude which approach is more effective.

Finally, this research can be beneficial for the readers in general, and those who are interested in second language and foreign language learning or teaching. Although this research is considered to be fundamental, it is expected that it can become a starter for young researchers.

\section{REFERENCES}

Bot, K. d., Lowie, W., \& Verspoor, M. (2005). Second Language Acquisition. New York: Routledge.

Brown, H. D. (2001). Teaching by Principles. New York: Pearson Education Company.

Coleman, H. (2011). Allocating resouces for English: The case of Indonesia's English medium International Standard Schools. Dalam H. Coleman, Dreams and Realities: Developing Countries and the English Language (hal. 87-112). Jakarta: British Council.

Crystal, D. (2003). English as A Global Language. United Kingdom: Cambridge University Press.

Ellis, R. (1994). The Study of Second Language Acquisition. Oxford: Oxford University Press.

Fortune, T. W., \& Tedick, D. J. (2003, August). What Parents Want to Know About Foreign Language Immersion Programs . Diambil kembali dari Centre for Applied Linguistics: http://www.cal.org/resources/digest/0304fortune.html

Genesee, F. (2007). The suitabiilty of french immersion for students who are atrisk: a review of research evidence. Canadian Modern Language Review, 655688.

Hadley, A. O. (2001). Teaching Language in Context 3rd Ed. Boston: Heinle \& Heinle Publishers.

Karsono, Puguh. (2014). Using Pictures in Improving the Speaking Ability of the Grade Eight-A Students of SMP Negeri 1 Anggana. Dinamika Ilmu Journal. Vo.14.No.2.December 2014: 191-214. 
Kirkpatrick, A. (2015, August 21-23). English as a Multicultural Language: Implications for ELT in Asia. 2015 TESOL Asia/Asian EFL Journal . Clark, The Philippines.

Krashen, S. D. (1981). Principles and Practice in Second Language Acquisition. English Language Teaching series. London: Prentice Hall International.

Maceda, C. (2014, July 28). Better English equals better pay. Dipetik August 25, 2015, dari Gulfnews.com: http://gulfnews.com/business/sectors/careers/betterenglish-equals-better-pay-1.1364562

Nurhayati, Dwi Astuti Wahyu. (2008a). Improving Students'English Vocabulary Mastery through Games (A Classroom Action Research in the Islam Kindergarten of Al-Irsyad Madiun in the Academic Year 2007/2008). Surakarta. Graduate School of Sebelas Maret University.

Met, M. (1987). Twenty Questions: The Most Commonly Asked Questions about Starting An Immersion Program. Foreign Language Anals 20 No. 4, 311-315.

Pesetsky, D. (2009). Linguistic Universals and Universal Grammar. Dipetik August 4, 2015, dari MITCognet.

Reviyanto, D. (2013, December 11). Jokowi Setuju Bahasa Inggris di Tingkat SD Dihapus . Dipetik August 16, 2015, dari Tempo Metro: http://metro.tempo.co/read/news/2013/12/11/064536601/jokowi-setujubahasa-inggris-di-tingkat-sd-dihapus

Romeo, K. (2000). Krashen and Terrell's "Natural Approach". Dipetik August 18, 2014

Roszandi, D. (2012, August 5). Kemampuan Guru Bahasa Inggris SMP Memprihatinkan . Dipetik August 24, 2015, dari tempo.co: http://nasional.tempo.co/read/news/2012/08/05/079421508/kemampuan-gurubahasa-inggris-smp-memprihatinkan

Suherdi, D. (2012). Rekonstruksi Pendidikan Bahasa. Bandung, Indonesia: Celtics Press.

White, L. (2003). Second Language Acquistion and Universal Grammar. Cambridge: Cambridge University Press. 